УДК 343.13

DOI https://doi.org/10.32782/2409-4544/2020-1/23

Б. Чупринський

\title{
Покарання за невиконання судового рішення за Кримінальним кодексом України
}

У статті досліджено особливості покарання за невиконання судового рішення за кримінальнімй законодавством України. Виконання судових рішень - один із основних критеріїв, за яким громадяни оцінюють спроможність, ефективність і чесність системи правосуддя в будь-якій державі. Натомість відсутність дієвого механізму забезпечення виконання судових рішень негативно впливає на авторитет судової влади, оскільки відтак не досягається кінцева мета правосуддя - захист інтересів громадян і реальне поновлення їхніх порушених прав. У контексті предмету дослідження оарактеризовано окремі положення про загальне поняття покарання, зміст і форма покарання у вітчизняному кримінальному законодавстві. На цій теоретичній основі проаналізовано види покарання за невиконання судового рішення і підстави для їх застосування. Вивчено пом'якшуючі $\mathrm{i}$ обтяжуючі обставини і вплив ст. 69 КК України на призначення покарання за вчинення вказаного злочину. Наголошено на необхідності чіткого обгрунтування судами застосування судового розсуду при прийнятті рішення у кримінальному провадженні про невиконання судового рішення. Межі покарань за злочин, передбачений ст. 382 КК України, встановленні у санкціях цієї статті $\epsilon$ необгрунтованими, оскільки вчинення злочину, передбаченого ч. 2 ст. 382 КК України, спеціальним суб'єктом є більш суспільно небезпечним, аніж учинення того ж посягання загальним суб' єктом. Якщо порівнювати санкції ч. 2 та ч. ч. 3, 4 ст. 382 КК України, то очевидно, що за менш суспільно небезпечне діяння судом може бути призначено суворіше покарання. Автор запропонував збільшити розмір покарання за вчинення злочину, передбаченого ч. 2 ст. 382 КК України, від однієї тисячі до двох тисяч неоподатковуваних мінімумів доходів громадян та збільшити мінімальний розмір основного покарання у санкції ч. 3 і 4 ст. 382 КК України до п’яти років позбавлення волі.

Ключові слова: покарання; злочин; кримінальна відповідальність; санкції; види покарання; призначення покарання; судове рішення.

Постановка наукової проблеми та її значення. Проблема забезпечення виконання судових рішень існує у суспільстві здавна і завжди становить інтерес для науковців. В Україні, згідно Конституції, правосуддя здійснюється виключно судами i обов'язковість рішень суду $\epsilon$ конституційною засадою судочинства (п. 9 ч. 3 ст. 129 Конституції України). Виконання судових рішень - один із основних критеріїв, за яким громадяни оцінюють спроможність, ефективність $\mathrm{i}$ чесність системи правосуддя в будь-якій державі. Натомість відсутність дієвого механізму забезпечення виконання судових рішень негативно впливає на авторитет судової влади, оскільки відтак не досягається кінцева мета правосуддя - захист інтересів громадян і реальне поновлення їхніх порушених прав. Тому держава має забезпечувати виконання судового рішення у визначеному законом порядку, а контроль за його виконанням покладається на суд (ст. ст. 124, 127, п. 9 ч. 3 ст. 129 , ст. 129-1 Конституції України). Саме тому суд ухвалює рішення іменем України, а судове рішення $\epsilon$ обов' язковим до виконання.

Проте, аналіз стану виконання судових рішень засвідчує, що наведені конституційні положення дуже часто порушуються. Забезпечення їх дотримання багато в чому залежить від широкого кола правових заходів, особливе місце серед яких займають кримінально-правові. Так, дотриманню обов'язковості виконання судових рішень, що набрали законної сили, сприяє закріплення у Кримінальному кодексі України ст. 382, яка передбачає кримінальну відповідальність за невиконання судового рішення, а кримінальна відповідальність тісно взаємодіє 3 кримінальноправовими засобами впливу на осіб, що вчинили кримінальні правопорушення і становить собою негативну оцінку в обвинувальному вироку суду за вчинення особою кримінального правопорушення і відповідно змушення винною особою зазнати конкретних заходів кримінально-правового характеру, заснованих на примусі (обмеженні прав і свобод особистого, майнового чи іншого характеру). А умисне невиконання судового рішення зумовлює обов'язкове державне реагування на подібний

(С) Чупринський Б., 2020 
злочинний прояв у вигляді застосування до відповідних суб’єктів заходів кримінально-правового характеру, одним із яких є кримінальна відповідальність.

Аналіз досліджень цієї проблеми. Окремі питання відповідальності за вчинення злочину передбаченого ст. 382 КК України були викладені в наукових працях М. І. Бажанова, О. О. Дудорова, О. І. Заліска, О. М. Литвинова， Л.В.Лобанової， В. І. Луганського， М. В. Мазура， В. П. Мороза, Р. І. Мельника, В. О. Навроцького, В. І. Тютюгіна, М. І. Хавронюка та ін. Однак чимало питань - i загальнотеоретичних, і тих, що безпосередньо стосуються проблеми боротьби зі злочинами у сфері охорони порядку виконання судових рішень, - досі є спірними. Не мають вони єдиного вирішення і в судовій практиці і потребують подальшого дослідження.

Формулювання мети статті. Розглянути поняття покарання, проаналізувати санкції ст.382 КК України, дослідити загальні та спеціальні засади призначення покарань за умисне невиконання судового рішення. Вивчити вплив обставини, які пом'якшують покарання та призначення більш м'якого покарання, ніж передбачено законом за вказане правопорушення.

Виклад основного матеріалу й обгрунтування отриманих результатів дослідження. Згідно з ч. 1 ст. 50 КК України покарання є заходом примусу, що застосовується від імені держави за вироком суду до особи, визнаної винною у вчиненні злочину, і полягає в передбаченому законом обмеженні прав і свобод засудженого, тобто, покарання - це форма кримінальної відповідальності, що полягає в найбільш істотному обмеженні правового статусу особи, яка вчинила злочин. В. С. Сгоров в своєму дослідженні зауважив, що покарання є основним заходом правового примусу, який являє собою форму державного впливу, що проявляється у застосуванні передбачених законом обмежень особистих або інших інтересів суб'єкта правого відношення для попередження заподіяння шкоди суспільним відносинам, забезпечення можливості досягнення соціально необхідного результату, а також надання позитивного впливу [4, с. 108].

Кожен вид покарання має чіткі межі та встановлений зміст, спосіб впливу на засудженого, чітко регламентований кримінальним законом, і ніхто не має права виходити за межі кількісних i якісних характеристик покарання, встановлених законом. Держава має виняткову монополію на призначення кримінального покарання. Вона визначає повноваження у сфері призначення та виконання покарання, встановлює підстави застосування покарання, види й мету покарання, визначає в КК України систему покарань - вичерпний і обов'язковий перелік видів покарань, розташованих у певному порядку залежно від ступеня їхньої тяжкості. Т. А. Денисова розглядає зміст покарання як сукупність певних правил, які містять обмеження і втрати, що застосовуються до засудженого (фізична ізоляція від суспільства; фізичні, моральні, майнові обмеження; порядок та умови виконання покарань тощо), а формою покарання вважає той чи інший вид покарання, що передбачений санкцією статті: ізоляція злочинця від суспільства у виді позбавлення волі, покладення обов'язку сплатити в дохід держави кошти тощо [3, с. 66]. I. I. Митрофанов вказує, що покарання має кілька особливих рис, які дозволяють точно визначити його зміст і відрізнити від інших видів державного примусу: всі види покарань передбачені в КК України; єдиною підставою для застосування покарання $є$ вчинення особою кримінально караного діяння, передбаченого КК України; Покарання носить публічний характер; специфічний зміст - лише покарання може бути пов'язано з тривалим позбавленням або обмеженням волі, повною конфіскацією майна, обмеженням інших найбільш значущих прав і свобод особистості; за своїм характером покарання носить суто індивідуальний характер; для покарання передбачена спеціальна процедура його призначення і реалізації; юридичним наслідком застосування покарання є правовий стан судимості [5, с. 385].

Аналіз санкцій ч. ч. 1-4 ст. 382 КК України засвідчує, що невиконання судового рішення карається за ч. 1 штрафом від п'ятисот до однієї тисячі неоподатковуваних мінімумів доходів громадян або позбавленням волі на строк до трьох років; за ч. 2 - штрафом від семисот п'ятдесяти до однієї тисячі неоподатковуваних мінімумів доходів громадян або позбавленням волі на строк до п'яти років, з позбавленням права обіймати певні посади чи займатися певною діяльністю на строк до трьох років; за ч. 3 - позбавленням волі на строк від трьох до восьми років 3 позбавленням права обіймати певні посади або займатися певною діяльністю на строк до трьох років; за ч. 4 - позбавленням волі на строк від трьох до восьми років з позбавленням права обіймати певні посади чи займатися певною діяльністю на строк до трьох років. Вказані види покарань становлять собою каральні заходи кримінально-правового характеру, що реалізуються в межах такого складного соціального явища як кримінальна відповідальність.

Згідно 3 ч. 1 ст. 53 КК України штраф - це грошове стягнення, що накладається судом у випадках і розмірі, встановлених в Особливій частині цього Кодексу, з урахуванням положень частини другої цієї статті. Ю. А. Пономаренко зазначає, що штраф являє собою грошову суму, яка 
стягується з особи, яка вчинила злочин, в дохід державного бюджету. У цьому сутність штрафу і його відмінність від інших видів покарання. Усі інші ознаки, що можуть привноситься в його понятті (як в легальному, так і в доктринальному визначенні), мало додає до його розуміння. Дослідник вказує, що за загальним визнанням українських криміналістів штраф є загальним видом покарання, тобто покарання, застосування якого не обмежене в законі ні колом суб'єктів, ні характером вчиненого злочину. У той же час, зауважує науковець, загальне коло суб'єктів, до яких може бути застосований штраф, має все ж таки один виняток - 3 нього виведені неповнолітні, які не мають самостійного доходу, власних коштів або майна, на яке може бути звернено стягнення [7, с. 49, 52-53].

Соціальна функція штрафу може бути успішно реалізована лише з урахуванням правової природи цього виду покарання. Він належить до групи майнових покарань. Штраф психологічно впливає на засудженого, підтверджуючи докір держави стосовно особи, яка вчинила злочин, та спричинює істотні матеріальні наслідки, які можуть зробити невигідними і небезпечними для злочинця подальше вчинення майнових та інших злочинів [3, с. 156]. У цілому штраф є досить ефективним видом як основного, так і додаткового покарання [8, с. 198].

Відповідно до ч. 1 і 2 ст. 55 КК України позбавлення права обіймати певні посади або займатися певною діяльністю може бути призначене як основне покарання на строк від двох до п'яти років або як додаткове покарання на строк від одного до трьох років. Позбавлення права обіймати певні посади як додаткове покарання у справах, передбачених Законом України «Про очищення влади», призначається на строк п'ять років. Позбавлення права обіймати певні посади або займатися певною діяльністю як додаткове покарання може бути призначене й у випадках, коли воно не передбачене в санкції статті (санкції частини статті) Особливої частини КК України за умови, що 3 урахуванням характеру злочину, вчиненого за посадою або у зв'язку із заняттям певною діяльністю, особи засудженого та інших обставин справи суд визнає за неможливе збереження за ним права обіймати певні посади або займатися певною діяльністю.

Під позбавленням права слід розуміти покарання, що складається в обмеженні права на працю особи, яка вчинила злочин, шляхом покладання на неї заборони працювати на певному колі посад або в певному колі сфер тривалості. Воно застосовується не до всіх осіб, а лише до тих, які мають певне право або займають певну посаду. Бо не можна позбавити людину того права, яке йому і не належить. Даної позиції дотримуються всі українські криміналісти, які присвятили свої дослідження даному виду покарання. Такої ж думки, в цілому, дотримується і судова практика[7, с. 75-76].

Згідно зі ст. 63 КК України покарання у виді позбавлення волі полягає в ізоляції засудженого та поміщенні його на певний строк до кримінально-виконавчої установи закритого типу. Позбавлення волі встановлюється на строк від одного до п’ятнадцяти років, за винятком випадків, передбачених Загальною частиною цього Кодексу. Позбавлення волі - це покарання, що складається в обмеженні права особи, яка вчинила злочин, на особисту свободу шляхом повної ізоляції ії від суспільства на строк, встановлений вироком суду. За загальним визнанням українських криміналістів цей вид покарання є загальним і чи не єдиним серед таких, які не мають ніякого встановленого в законі обмеження по колу застосування. 3 цим, в цілому, можна погодитися 3 тим лише застереженням, що ч. 2 ст. 102 КК України забороняє призначати позбавлення волі неповнолітньому, який вперше вчинив злочин невеликої тяжкості [7, с. 210-211].

Вказані види покарання призначаються судом у межах, установлених у санкції статті (санкції частини статті) Особливої частини КК України, що передбачає відповідальність за вчинений злочин, за винятком випадків, передбачених ч. 2 ст. 53 КК України; 2) відповідно до положень Загальної частини КК України; 3) враховуючи ступінь тяжкості вчиненого злочину, особу винного та обставини, що пом'якшують та обтяжують покарання. Особі, яка вчинила злочин, має бути призначене покарання, необхідне й достатнє для іiі виправлення та попередження нових злочинів. Більш суворий вид покарання з числа передбачених за вчинений злочин призначається лише у разі, якщо менш суворий вид покарання буде недостатній для виправлення особи та попередження вчинення нею нових злочинів (ч. 1 і 2 ст. 65 КК України).

Це так звані загальні засади призначення покарання. В. М. Трубніков виділяє наступні риси, властиві загальним засадам призначення покарання: вони покликані сприяти реалізації кримінальноправових санкцій при визначенні конкретного покарання в точній відповідності до закону; сформульовані в законі вимоги є загальними, тобто стосуються усіх випадків призначення покарання, загальні засади, на відміну від принципів, мають локальний характер, тобто визначають той або інший бік призначення покарання [9, с. 101-102]. Крім того, суд може призначати ці покарання, керуючись ще й спеціальними засадами їх призначення, що фактично закріплені у ч. 3, 4, 5 ст. 65 КК України та ст. ст. 68-72 КК України. 
А. М. Ященко, зауважує, що характеризуючи ступінь тяжкості вчиненого злочину, особу винного та обставини, що пом'якшують та обтяжують покарання, не слід ототожнювати обставини, що характеризують ступінь тяжкості вчиненого злочину або особу винного, 3 обставинами, що обтяжують або пом'якшують покарання. Сутність останніх полягає у тому, що вони можуть бути такими, що характеризують ступінь тяжкості вчиненого злочину або особу винного. Саме за цією їх ознакою багатьма науковцями наводиться класифікація обставин, що пом'якшують або обтяжують покарання. Однак, у разі якщо будь-які обставини, що характеризують ступінь тяжкості вчиненого злочину або особу винного, враховані судом як пом'якшуючі або обтяжуючі покарання, вони повинні визнаватися такими і не мають одночасно ще братися до уваги при врахуванні ступеня тяжкості злочину і особи винного. Крім того, визнання будь-якої обставини пом'якшуючою не повинно здійснюватися формально, виходячи із суб'єктивного ставлення судді до якоїсь конкретної встановленої у кримінальному провадженні обставини. Корисними у такому разі можуть стати роз'яснення вищої судової інстанції, адже лише вища судова інстанція у результаті узагальнення відповідної судової практики може прийти до висновку, що ті чи інші обставини є такими, що пом'якшують покарання [11, с. 145-152].

Зазначені погляди варто дотримуватися під час практичної реалізації встановленого у санкціях ст. 382 КК України конкретного виду та розміру покарання. До цього слід додати і те, що реалізація спеціальних засад призначення покарання за цей злочин має свої особливості. Зокрема, на них звертає увагу Г. І. Богонюк. Так, на думку дослідниці, призначення більш м'якого покарання, ніж це передбачено кримінальним законом (ст. 69 КК України), за невиконання судового рішення (ст. 382 КК України) не завжди відбувається обгрунтовано. Особливістю законодавчої конструкції ст. 69 КК України $\epsilon$ те, що в ній не конкретизовано, які саме пом'якшуючі обставини слід уважати такими, що істотно знижують ступінь тяжкості вчиненого злочину, наскільки істотно суд має право пом'якшити покарання, до якого саме виду основного покарання, не зазначеного у кримінально-правовій санкції, має право перейти суд. Такий підхід нерідко призводить до «огульного використання» відповідної кримінально-правової норми. У зв'язку з цим, реалізація ст. 69 КК України у випадку вчинення злочину, передбаченого ст. 382 КК України, вимагає від судів з'ясування того, які саме пом'якшуючі обставини істотно знижують ступінь тяжкості вчиненого злочину і в якому саме ступені відбувається таке зниження [2, с. 150-151].

При призначення покарання за невиконання судового рішення, в межах установлених у відповідній санкції цієї статті, суд керується не лише зазначеними вище загальними та спеціальними засадами чи правилами. Суд призначає покарання також керуючись і власним судовим розсудом. Таке право надається суду вітчизняним законодавцем, який у санкціях статей Особливої частини КК України регламентує конкретні види покарань і межі, в яких вони мають бути призначенні. В. П. Мороз зазначає, що передбачена вітчизняним законодавцем санкція за вчинення даного злочину має надмірно великі межі між нижчим та вищим рівнем основного покарання у виді позбавленні волі (від 1 до 8 років) [6, с. 177].

Г. І. Богонюк також стверджує, що межі покарань за злочин, передбачений ст. 382 КК України, встановленні у санкціях цієї статті є необгрунтованими. Зокрема, за невиконання судового рішення, вчиненого загальним суб'єктом, як одне із альтернативних видів покарання, передбачено штраф у розмірі від п'ятисот до однієї тисячі неоподатковуваних мінімумів доходів громадян. Натомість за вчинення тих же дій службовою особою (ч. 2 ст. 382 КК України) передбачений штраф від семисот п'ятдесяти до однієї тисячі неоподатковуваних мінімумів доходів громадян. Очевидно, в обох частинах статті передбачена однакова міра максимального покарання у розмірі однієї тисячі НМДГ. Однак це не є виправданим, оскільки вчинення злочину, передбаченого ч. 2 ст. 382 КК України, спеціальним суб'єктом є більш суспільно небезпечним, аніж учинення того ж посягання загальним суб'єктом. Відповідно, і розмір покарання повинен це відображати. Тому слушною є пропозиція Г. І. Богонюк збільшити розмір покарання за вчинення злочину, передбаченого ч. 2 ст. 382 КК України (від однісї тисячі до двох тисяч НМДГ) КК України.

Окрім того, ч. 2 ст. 382 КК України як альтернативне покарання передбачає позбавлення волі на строк до п'яти років із позбавленням права обіймати певні посади чи займатися певною діяльністю на строк до трьох років. Натомість, ч. 3 ст. 382 КК України передбачене покарання у виді позбавлення волі на строк від трьох до восьми років із позбавленням права обіймати певні посади або займатися певною діяльністю на строк до трьох років, якщо невиконання рішення суду вчинене службовою особою, яка займає відповідальне чи особливо відповідальне становище, або особою, раніше судимою за злочин, передбачений цією статтею, або якщо вони заподіяли істотну шкоду, що вказує на більш високий ступінь його суспільної небезпеки. Така ж міра покарання передбачена і в ч. 4 ст. 382 за 
умисне невиконання службовою особою рішення Європейського суду 3 прав людини. Якщо порівнювати санкції ч. 2 та ч. ч. 3, 4 ст. 382 КК України, то очевидно, що суд за невиконання судового рішення службовою особою (ч. 2 ст. 382 КК України) може призначити більш суворе покарання, ніж учинення цього ж злочину службовою особою, яка займає відповідальне становище, а також яке заподіяло істотну шкоду (ч. 3 ст. 382 КК України). Відтак, за менш суспільно небезпечне діяння судом може бути призначено суворіше покарання і навпаки, що засвідчує те, що аналізовані санкції побудовані зі суттєвим порушенням законів юридичної логіки та законодавчої техніки. На підставі наведеного дослідниця пропонує мінімальний розмір основного покарання у санкції ч. 3 і 4 ст. 382 КК України збільшити до п’яти років позбавлення волі [2, с. 149-150].

Висновки. На основі викладеного варто наголосити, що чинне кримінальне законодавство України потребує постійного вдосконалення й приведення кримінально-правових санкцій у відповідність із умовами сьогодення та із усталеними принципами їх побудови. Варто підтримати наведену вище точку зору Г. І. Богонюк і збільшити розмір покарання за вчинення злочину, передбаченого ч. 2 ст. 382 КК України, від однієї тисячі до двох тисяч НМДГ та збільшити мінімальний розмір основного покарання у санкції ч. 3 і 4 ст. 382 КК України до п’яти років позбавлення волі, оскільки запропоновані дослідницею пропозиції грунтуються на вироблених доктриною кримінального права засадах і принципах формування санкцій Особливої частини КК України. Також при побудові кримінально-правових санкцій варто врегулювати амплітуда між нижчими та вищими межами покарання у вигляді позбавлення волі, яка є необгрунтовано великою. Отже покарання в КК України мають відповідати потребам сучасності, санкції мають побудовані 3 дотриманням законів юридичної логіки, чітко деталізовані і обгрунтовані у суддівського розсуду при винесенні вироку суду.

\section{Джерела та література}

1. Бершов Г. Є. Кримінальна відповідальність за втручання в діяльність судових органів: автореф. дис. на здоб. наук. ступ. канд. юрид. наук: спец. 12.00.08: кримінальне право та кримінологія; кримінально-виконавче право / Г. Є. Бершов. - Х., 2013. - 19 с.

2. Богонюк Г. І. Кримінально-правова характеристика невиконання судового рішення: дис. ... канд. юрид. наук: 12.00.08 / Галина Іванівна Богонюк. - Львів, 2016. - 201 с.

3. Денисова Т. А. Покарання: кримінально-правовий, кримінологічний та кримінально-виконавчий аналіз: монографія / Т. А. Денисова. - Запоріжжя: КПУ, 2007. - 288 с.

4. Егоров В. С. Вопросы правового регулирования мер уголовного принуждения: моногр. / В. С. Егоров. - М.: Изд-во Москов. психол.-соц. ин-та; Воронеж: Изд-во НПО «МОДЭК», 2006. $312 \mathrm{c}$.

5. Митрофанов И. И. Уголовно-правовое учение о механизме реализации уголовной ответственности: монографія / И. И. Митрофанов. - Одесса: Фенікс, 2014. - 446.

6. Мороз В. П. Кримінальна відповідальність за невиконання судового рішення: досвід країн СНД / В. П. Мороз // Право і суспільство. - 2011. - № 6. - С. 173-177.

7. Пономаренко Ю. А. Виды наказаний по уголовному праву Украины: монографія / Ю. А. Пономаренко. - Х.: Изд-во ФИНН, 2009. - 344 с

8. Попрас В. О. Штраф як вид покарання за кримінальним правом України: монографія / В. О. Попрас. - Х.: Право, 2009. - 224 с.

9. Трубніков В. М. Арешт як вид кримінального покарання та особливості його застосування: моногр. / В. М. Трубников, Ю. В. Шинкарьов. - Х.: Харків юридичний, 2007. - 288 с.

10. Уманець Б. Б. Поняття кримінально-правових санкцій та встановлення їх меж / Б. Б. Уманець // Часопис Київ. ун-ту права. - 2016. - № 1. - С. 315-321.

11. Ященко А. М. Застосування заходів кримінально-правового характеру: монографія / А. М. Ященко. - Х.: НікаНова, 2014. - 388 с.

Чупринский Б. Наказание за невыполнение судебного решения в Уголовном кодексе Украины. В статье исследуются особенности наказания за невыполнение судебного решения по уголовному законодательству Украины. Исполнение судебных решений - один из основных критериев, по которым граждане оценивают способность, эффективность и честность системы правосудия в любом государстве. Отсутствие действенного механизма обеспечения выполнения судебных решений отрицательно влияет на авторитет судебной власти, поскольку поэтому не достигается конечная цель правосудия - защита интересов граждан и реальное обновления их 
нарушенных прав. Характеризуется понятие наказания, определено содержание и форма наказания в отечественном уголовном законодательстве. Анализируются виды наказания за невыполнение судебного решения и основания их применения. Изучены смягчающие и отягощающие обстоятелства и влияние ст. 69 УК Украины на назначение наказания за совершение указанного преступления. Отмечена необходимость четкого обоснования судами применения судебного усмотрения при принятии решения по изученной категории дел. Границы наказаний за преступление, предусмотренное ст. 382 УК Украины, установленные в санкциях данной статьи, являются необоснованными, поскольку совершение преступления, предусмотренного ч. 2 ст. 382 УК Украины, специальным субъектом является более общественно опасным, чем совершения того же посягательства общим субъектом преступления. Если сравнивать санкции ч. 2 и ч. ч. 3,4 ст. 382 УК Украины, то очевидно, что при менее общественно опасном деянии судом может быть назначено более строгое наказание. Автор предложил увеличить размер наказания за совершение преступления, предусмотренного ч. 2 ст. 382 УК Украины, от одной тысячи до двух тысяч необлагаемых минимумов доходов граждан и увеличить минимальный размер основного наказания в санкции ч. 3 и 4 ст. 382 УК Украины до пяти лет лишения свободы.

Ключевые слова: наказание; преступление; уголовная ответственность; санкции; виды наказания; назначение наказания; судебное решение.

Chuprinsky B. Punishment for Failure to Comply with a Court Decision in Accordance with the Criminal Code of Ukraine. The article examines the features of punishment for failure to comply with a court decision under the criminal legislation of Ukraine. Enforcement of judicial decisions is one of the main criteria by which citizens assess the capacity, efficiency and fairness of the justice system in any state. Instead, the lack of an effective mechanism to ensure the enforcement of court decisions negatively affects the authority of the judiciary, as it does not achieve the ultimate goal of justice - to protect the interests of citizens and the real restoration of their violated rights. The concept of punishment is characterized, the content and form of punishment in the domestic criminal legislation is determined. The types of punishment for failure to comply with a court decision and the grounds for their application are analyzed. Mitigating and aggravating circumstances and the impact of Art. 69 of the Criminal Code of Ukraine in imposing punishment for committing the specified crime were examined. The need for a clear justification by the courts of the application of judicial discretion in making a decision is noted. Limits of punishment for the crime provided by Art. 382 of the Criminal Code of Ukraine, established in the sanctions of this article are unfounded, because the committing a crime according the Part 2 of Art. 382 of the Criminal Code of Ukraine, a special subject is more socially dangerous than committing the same encroachment by a general subject. If we compare the sanctions of Part 2 and Part 3, 4 of Art. 382 of the Criminal Code of Ukraine, it is obviously that for a less socially dangerous act the court may impose a more severe punishment. The author proposed to increase the penalty for committing a crime under Part 2 of Art. 382 of the Criminal Code of Ukraine, from one thousand to two thousand non-taxable minimum incomes and increase the minimum size of the main punishment in the sanctions of Part 3 and 4 of Art. 382 of the Criminal Code of Ukraine up to five years in prison. judgment.

Key words: punishment; the crime; criminal liability; sanctions; types of punishment; sentencing; 